\title{
MATERIAEY
}

Eyal Peled

BHW 42/2020

(Independent Researcher, Haifa, Israel)

ISSN 1233-2224

ORCID: 0000-0002-4218-7630

DOI: $10.14746 /$ bhw.2020.42.7

\section{The History of Education System and Authority in Israel from the Ottoman period to our days}

\begin{abstract}
During the short history of its existence, even before the state of Israel was born, the Education system in the area known today as Israel has constantly faced the challenge of providing equal, or at least somewhat state-controlled curriculum, budgeting and education in general. During the major periods of government change, various religious, socioeconomic and political groups had tried to reshape the education system to match their needs, creating schools, programs and funding plans accordingly. However, despite the evolving legislation and awareness, the Israeli Education System is heavily segregated based on religion, origins, and other factors. Whole populations are exempted by choice, or by lack of lobbying, while the main system remains to bring equity to a highly heterogenic school system. This article will show the challenges, stratification changes and shifts the system has faced on the way to provide quality education to the children of Israeli state.
\end{abstract}

Keywords: education, integration, segregation, education streams, Israel

\section{Introduction}

Israel is a quite young state, "born" in 1948, but the forming of it as a whole entity has begun much earlier. Since the awakening in the last years of the $19^{\text {th }}$ century, the state has undergone major political changes, shifting from separated, unorganized settlement to a single functioning state. The British Mandate was seemingly meant to promote such unification as part, however on practice it pretty much allowed the population to do as they please, including education-wise ${ }^{1}$, while focusing only on raising

\footnotetext{
1 Tnuat Ha-Avoda, Hinuch betkufat hamandat [Education during the Mandate (2019). Retrieved from https://nuathaavoda.info/education/home/7/1109679617.html.
} 
the next generation of civil servants for the great British Empire ${ }^{2}$. Despite everything, as there was an official plan to later create an independent state in the area, initial forms of legislation took place, including on the shaping of education.

Later, as the state was born and evolved, the system of education has faced constant challenges of attempting to serve a very diverse population, based on religion, level of religiosity, agenda of local political organization and so on $^{3}$. This paper will show the shifts and challenges of the main education system of Israel over the years, focused on coping with agendas, legislation and existing practice for the purpose of demonstrating the historical forming and constant challenges of the endlessly evolving education system of Israel.

\section{Pre-Israeli education}

\section{Pre-British Mandate}

The earliest known form of education in the area known today as Israel had carried a traditional, religious tone, with the Jewish and the Arab education systems evolving independently. The Jewish system was led by private, traditional "old settlement", meaning families which, according to some authors, never actually left to any diaspora, this education wasn't led by any standard, lacked a central direction and mostly maintained the existing culture without much innovation ${ }^{4}$. However, others claim that despite the majorly religious focus, those schools, led by the Oriental (Mizrakhi) Jews, had included general studies since 1909 , amounting to about $50 \%$ of the total education hours 5 .

The Arab system was more organized, with a known number of about 95 primary schools and 3 high schools, the curriculum of which was dictated by the Ottoman Empire. Little is known about the quality of education or the financial accessibility of those schools ${ }^{6}$. In addition, a parallel private system of 379 schools existed, focusing more on religious studies ${ }^{7}$. Both systems had prioritized male students, with girls being less than $20 \%$ of the total student population.

${ }^{2}$ H. Rahman, Education in Palestine: Current challenges and emancipatory alternatives, Ramallah 2015, p. 2.

3 S. Swirski, Hinuch be-Israel: mahoz hamaslulim hanifradim [Educaiton in Israel: schooling for inequality]. Tel-Aviv 1990, pp. 17-33.

${ }^{4}$ R. Alboim-Dror, Memshelet ha-mandat vehahinuch ha-ivri: tguvat hayeshuv lekolonializm tarbuti [The Mandate administration and the Hebrew education: the response of settlement to the cultural colonialism]. "Katedra" 1995, 75, p. 95.

${ }_{5}$ M. Davidson, The rise and the implementation of the State Education Law, 1953 [Doctoral dissertation]. Tel-Aviv University, Israel 2002, p. 198.

${ }^{6}$ E. Greenberg, Preparing the mothers of tomorrow: education and Islam in mandate Palestine. University of Texas Press 2002; H. Rahman, op. cit., p. 2.

7 S. Swirski, op. cit., p. 15. 
Since the late $19^{\text {th }}$ century, as the Jewish settlement in Israeli region has begun to grow, there has been a demand for education. An inflow of financial support from the European Diaspora has enabled opening more schools, with an inflow of more secular, western ideas. And while there was no intended offence to the existing population, some tension has formed between the more traditional "old settlement" to the more modern "new settlement". Schools were opened according to the demand and by the support of a specific population, which also determined the quality and speciality of the school. Such education wasn't obligatory, and more than that, it was financially supported by the parents of the students and private donation, and still, over $90 \%$ of the Jewish population of that period was literate. However, as schools were population specific, this high percentage didn't include the Arab population, nor the Mizrahi (“oriental") Jews. Also, despite the overall literacy, $62 \%$ of the students didn't graduate, completing 1-3 classes out of possible $8^{9}$.

During this period, mixed Jewish-Arab schools existed, especially in mixed cities such as Jaffa and Haifa ${ }^{10}$.

\section{The British Mandate era (1920-1948)}

In 1917, as soon as the interregnum between the Ottoman and the British empires took place, the education system started to reform to match the already proclaimed, but not quite settled British Mandate along with the land, and as such the Arab population had to follow the same laws as the Jewish population. However, this system was criticized for not accepting diversity, but rather having a clear objective of training servants for the British Empire ${ }^{11}$. For example, the primary education for women was only available for the first 4 years, during which the focus was made on domestic roles, acceptable both by the British administration and the locals. The efficiency of such "education" for women meant that Arab girls were only $21 \%$ of the government school pupil population, and only $7.5 \%$ of village girls receiving any education at all ${ }^{12}$. The British empire has even enabled racial segregation. For example, under their control the mixed schools practically ceased to exist after the bloody events of 1929 , which took place in $\mathrm{Jaffa}^{13}$. With hostility clearly set between Jews and Arabs, mixed schools aren’t considered a safe option.

\footnotetext{
${ }^{8}$ R. Alboim-Dror, op. cit., p. 101.

${ }^{9}$ I. Kashti, Maarechet haHinuch beIsarael: hinuch betkufat hamandat habriti [The education system of Israel: education in the British Mandate era], in: Ishim ve-maasim beIsrael: sefer hayovel, eds. S. Aharoni, M. Aharoni, 1998.

${ }^{10}$ U. Shwed, Y. Shavit, M. Dellashi \& M. Ofek, Policy Paper 2014.12. Integration of Arab Israelis and Jews in Schools in Israel, Taub-Center, Israel 2014, p. 325.

11 H. Rahman, op. cit., p. 2.

12 E. Greenberg, op. cit., p. 70.

${ }^{13}$ U. Shwed et al, op. cit.
} 
On the other hand, since the Balfour declaration in 1917 the Jewish population of the region saw the British reign as a sign for a nation being reborn. As part of it, there was a demand for organized education. As far as the British administration was concerned, there was no difference between the Jewish and the Arab schools, and each population group was allowed to open and maintain its own schools as part of pluralism approach ${ }^{14}$. The earliest relevant legislation regarding education was the Education bill (1933) which held various definitions for schools, such as permitting religious and secular programs and roles of teachers and headmasters, including various penalties for not following the law. The education format was meant for 8 classes, with registration being left for the parents to decide.

But even before the bill, there was a call for order in the system from the Jewish settlement. In 1928, following a long discussion by the representatives of the Zionist Union, the teachers' union and general population has defined three main "streams"permitted directions of development of the education system:

- The general stream- the oldest of the three, responsible for $45 \%$ of the kindergartens, $49 \%$ of the common schools and $87 \%$ of the high schools. Those schools didn't associate themselves with one brand of Zionism or the other and simply focused on civil circles. Those schools had a clear curriculum since 1925, which didn't change much until 1953, when a state-wide curriculum was enforced by law.

- The Oritental Jewish (Mizrakhi) stream, being Zionist-religious, covering 18\% of the kindergartens, $27 \%$ of the schools and $10 \%$ of the high schools. Had a base curriculum planned since 1924, but applied it in practice only in 1932.

- The Workers' (Labour) stream has belonged to the Worker Union and has covered $37 \%$ of the kindergartens, $23 \%$ of schools, but only $3 \%$ of high schools. It had no clear single outline up to 1937 , and even then, the plan kept changing up to $1953^{15}$.

\section{Criticism}

There are several points of criticism known for the pre-Israeli education. The first one is the lack of clear, updated guidelines regarding the quality and content of the education. Despite the Education bill (1933), each stream and nationality kept evolving in its' own direction ${ }^{16}$, stratifying and dividing the population ${ }^{17}$.

More than that, every curriculum was set to serve a point of interest of the ruling administration. In the case of the Arab system, first it served the Ottoman administration,

\footnotetext{
14 Tnuat Ha-Avoda, op. cit.

15 Ibidem.

16 Ibidem.

17 S. Swirski, op. cit., p. 7.
} 
leaving the choice of either having a heavily biased state-guided content or the unchanging private system which heavily promoted the religious agenda. Then it served the needs of the British Mandate for civil servants with limited self- definition ${ }^{18}$, while maintaining oppression of the female population, as woman education was known for helping the women to "form opinions and... reject superstitions ${ }^{19}$.

Either way, clearly such education was set to divide, being unable to provide high-quality, standardized education for a land that was awaiting its independence based on the Balfour declaration.

\section{Early period (1949-1953)}

\section{Development of structure and curriculum}

Since it's becoming, the state of Israel initially relied on the British and Osman legislation. However, in 1949 the Knesset passed the first law regarding education: The Compulsory Education Law. This law required to enrol any child aged 3-14 into the education system according to his age and place of residence. Any apprentice could start at age 15, and continue his training as part of obligatory education. This law has determined that the Arab, Jewish, secular or religious schools all were required to accept students, and to follow certain government guidelines. The system had to follow a plan of $8+4$, meaning 8 classes of elementary school and 4 of high school ${ }^{20}$.

However, due to the chaos of the new-born state, there was a shortage of classes and teachers, and each population had to manage by its own resources. In addition, the lack of clear authority separation led to military interference in allocating population to schools. As a result, the Jewish and Arab streams grew further apart, with each forming as an autonomous system. Even the main teaching language varied: Hebrew for Jewish schools and Arabic for Arab schools, with only 5 bilingual schools existing ${ }^{21}$.

In addition, most of the state services, including education, were run by various political organizations, including military, thus lacking unity and order

In 1953, the State Education Law was enacted, initially meant to put an end to the various streams and semi-private education groups and set a state-approved, quality controlled curriculum. In fact, it defined that $75 \%$ of the curriculum of the schools was state mandated and obligatory, leaving $25 \%$ for the unique stream content (religious and ethnic aspects) ${ }^{22}$. It clearly defined the streams acceptable by the state and ended the

\footnotetext{
18 H. Rahman, op. cit., p. 2.

19 E. Greenberg, op. cit., p. 18.

${ }^{20}$ H. Ayalon, N. Blass, Y. Feninger \& Y. Shavit. I shivyon behinuch memechkar lemediniyut [Educational inequality: from research to policy]. Jerusalem: Taub center 2019, p. 81.

${ }^{21}$ U. Shwed et al., op. cit., p. 340.

22 Ibidem, p. 326.
} 
multiple ultra-secular streams such as "Workers" (Labour), with more freedom given to the Jewish Orthodox streams. Each political party, included the Arabs, has tried to lobby for its' own population, however not all has succeeded ${ }^{23}$. Even more so, the leading party, such as the pro-communist Labour, which represented about $43 \%$ of the general population, ended up absorbed into the "general" education stream.

Thus, while officially there was now a law on education requirements free of organizational bias, in practice even the law itself was written and passed based on significant political lobby pressure. As a result, the resulting law couldn't really provide the required equality in education.

\section{The stratification issue}

While the law clearly stated that all students are entitled to schooling, the quality of the schooling itself wasn't homogenous. One of the reasons for it was the stratification based on socio-economic and ethnic background. Even within the Jewish population itself, the European and the Oriental groups didn't mix. According to some sources, during the 70's and 80 's most of the students went to ethnically homogenous schools and classes- $70 \%$ of the $6^{\text {th }}$ grade students went to school where up to $80 \%$ of the students were of the same ethnic background ${ }^{24}$. The ethnic stratification has been maintained and even increased as the European Jewish population has migrated towards the central cities, such as Tel-Aviv, while the Oriental and later the Ethiopian population has settled in the periphery ${ }^{25}$.

An additional problem actually rose from the State Education Law (1953). The purpose behind the law was to set a frame for the Israeli Education system, of Israeli culture, loving the land, loyalty to the state and the people of Israel, agricultural and artisan practice and so on. In other words, it was meant to create a system which leads a young person into his role in future society ${ }^{26}$. However, the curriculum didn't sit well with the Arab stream, since the values and preferred literature pieces matched more the dominant Jewish population than the Arab minority ${ }^{27}$.

Another stream that didn't feel that the Labor/General program fits them is the Oriental/Religious program. The state curriculum was quite secular, which the Oriental

${ }_{23}$ Al-Hamishmar, Memshelet MAPAI- Zionim Klaliim heevira ba-Knesset "Hok Hinuch Mamlachti" ubecach hisla zerem haovdim vehizka hazramim hadatiim [The MAPAI government had passed the State Education Law and by doing so has ended the Labour stream and strengthened the religious streams]. Al-Hamishmar [1968, April 30]. Retrieved from http://jpress.org.il/olive/apa/nli_heb/SharedView.Article.aspx?href=AHR/ 1968/04/30\&id=Ar04400

${ }^{24}$ H. Ayalon et al., op. cit., p. 79.

25 Ibidem, pp. 50-51.

${ }^{26}$ Knesset, Hok Hinuch Mamlachti - 1953; Hok Limud Hova - horaot shaa - 1953 Kria rishona. [The State Education law - 1953; Compulsory Education law - temporary orders - 1953. First reading]. Jerusalem 1953.

${ }^{27} \mathrm{~K}$. Arar, Israeli education policy since 1948 and the state of Arab education in Israel. "Italian Journal of Sociology of Education” 2012, p. 1. 
Jews criticized for not allowing sufficiently religious upbringing for their children. Thus during the coining of the State Education Law (1953), special provisions were made for the religious schools, with religious teachers and inspectors, as long as the basic school outline is maintained according to $\mathrm{law}^{28}$. Some even more religious schools, such as Agudat Israel, had been recognized as fully independent streams, with even less state involvement and control of the curriculum, even if that meant reduced budgeting. For example, Orthodox schools which are recognized by the state accept obligation to teach at least $55 \%$ of the core subjects, and in return are $55 \%$ funded by the state ${ }^{29}$.

\section{The shift of political narrative}

As the preference for promoting labour and agriculture began to fall, different content was introduced. For example, during the 1980's it finally became first acceptable, then obligatory, to teach the subject of Holocaust, although it was limited to the high school history classes and lacked a clearly set narrative ${ }^{30}$. It replaced the narrative of the Zionist past, and memory through Israeliness and self-reliance with enforced, indoctrinated grief for the historical suffering. In addition, the narrative of national identity shifted from a clearly Jewish to "nation of all its citizens", with terms of democracy, pluralism and rule of law introduced a part of Civics subject for matriculation exam in the $11^{\text {th }}$ (out of 12) grade ${ }^{31}$.

\section{Criticism}

One of the main points of criticism for the school policy of that period was the failure to fully integrate the Arab society. While maintaining the autonomy allowed to build the fully Arab identity, the lack of joined education kept the population from forming a joint identity that wasn't a single nationality-centred ${ }^{32}$.

Another form of criticism was that the new law hadn't really ended the overabundance of streams. For example, despite the clear anti-Labor program, the kibbutz education

${ }_{28}$ M. Davidson, op. cit., p. 46

${ }^{29}$ T. Harel Ben-Shahar, Asdara shel batei sefer pratiim bareranim: beit sefer Havrota kemikre mivhan [Regulation of private selective schools: Havrota school as case study]. Jerualem: Van Leer Jerusalem Institute 2012, p. 4.

30 A. Zondberg, Bein hurban lanizahon-mashmaut ha Shoah berei haitonim hayomiim beisrael 1948-2003 [Between destruction and victory - the meaning of Holocaust as represented in the daily Israeli newspapers 1948-2003]. In: Sikur kesipur, mabatim al siah hatikshoret be-Israel, eds. M. Neiger, M. Blondheim \& T. Libs, Israel Magnes 2008, pp. 191-215.

31 J. Resnik, 'Sites of memory' of the Holocaust: shaping national memory in the education system in Israel. "Nations and nationalism", p. 307-308.

${ }^{32}$ U. Shwed et al., op. cit., p. 327. 
system has still maintained the unique characteristics of pro-communist approach. In addition, despite seemingly being merged into the general stream, the leaders responsible for the curriculum planning and finances still remained Labour party loyalists ${ }^{33}$.

In other words, despite the apparent attempt to make education available for larger population and to control its quality, the result was maintaining most of the streams, while deepening the gap between certain populations.

\section{The reform of 1970's}

Starting 1968 the Ministry of Education has decided to pay attention to the stratification issue among the students. In order to promote improving students' achievement, reducing socioeconomic gap in classrooms and promote future integration of the students into the workforce, the existing education policy was analysed and changes were offered based on the new political climate ${ }^{34}$. The decision was made not through legislation, but through applying the findings of Rimalt committee into practice. The objective of the reform was to increase the number of students attending high school, which up to that point didn't fall under the Compulsory Education Law (1949). The key changes were:

- Changing the school plan from binary $(8+4)$ to trinary $(6+3+3)$, meaning 6 years of elementary school, 3 years long middle school and 3 years of high school, applied in $1966^{35}$.

- Requiring registration based on geographic location, as opposed to parents' choice.

- Requiring all students graduating elementary schools to immediately continue their education in middle school.

- Setting class makeup with students from mixed socio-economic background ${ }^{36}$.

This reform was a result of the Yom Kippur war, which was perceived as a failure of government policies, and enabled a complete shift in power. This meant that the opposition, especially the Ashkenazi middle class, was elected as the new government. This government was no longer based on existing biography, but the popular vote, and as such, the education policy has begun to shift depending on the will of government in power, claiming integration, but leading to polarization ${ }^{37}$.

${ }^{33}$ Al Hamishmar, op. cit.

${ }^{34}$ H. Gaziel, Politics and Policymaking in Israel's Education System. Portland: Sussex Academy Press 1996, p. 4.

${ }^{35}$ H. Ayalon et al., op. cit., p. 81.

${ }^{36}$ A. Barak-Medina, Hakzaat mash'abim behinuch, ikaron haintegracia vebatei sefer yehudiim bemigzarim shonim [Resource allocation in education, the integration principle and unique schools in different sectors]. Jerusalem: Knesset 2003. Retrieved from: https://fs.knesset.gov.il/globaldocs/MMM/16e41ac7-9332-e811 -80de-00155d0a0235/2_16e41ac7-9332-e811-80de-00155d0a0235_11_6987.pdf, p. 15.

${ }^{37}$ H. Gaziel, op. cit. 
However, despite the general call for integration, the Independent- Orthodox schools were exempt from the change. For example, where the classes were expected to have at least $60 \%$ of well-off students, in order to bring quality teachers and promising students into the fold, in the Orthodox schools there were only $27 \%$ of well-off students, the others being classified as "grooming requiring" 38 . The secularization expected in the education has intimidated the religious groups, and pushed the Oriental Jews further away from the mainstream education, including the state-supported religious schools. While the more prestigious high schools almost openly pushed the Oriental students to drop out, in the trade schools the rate of Oriental to Ashkenazi students was 4 to 1 , while in agricultural schools the Oriental students rate was two to one Ashkenazi. They also composed $88 \%$ of the religious schools, and over $90 \%$ of the religious agricultural schools. In addition, the professional education system was highly gender segregated. ${ }^{39}$. If anything, the practice of placing religious middle and high schools near each other had created geographic difficulties up to a point where parents had to choose between sending their children to boarding school (extra fees included) or to deny the children their traditions and enrol them into nearby secular schools ${ }^{40}$.

Later examination of the integration plan by the State Comptroller has found that the plan has failed. In the Arab schools it was practically ignored, while in the Jewish schools, some integrated schools had segregated classes, based on socio-economic factors, with different study plans and quality gap ${ }^{41}$.

Another innovation that took shape in that period is the "unique schools". While the law dictated $75 \%$ of the curriculum, the remaining $25 \%$ was widely interpreted by some organizations, leading to the birth of schools specializing in arts, sciences or additional religious classes. Those schools, while still classified as state stream schools, had used the unique traits to attract the preferred audience, and to handpick talented students from other schools in the region ${ }^{42}$. While according to the law, only Orthodox schools are allowed to be unique, secondary regulation leaves an opening for the Minister of Education to grant a permit for a school to have unique programs, with the school still funded $60 \%$ by the state ${ }^{43}$.

In other words, while on paper there was a requirement for integrated classes, many schools found a way around it, using stream or unique traits to "skim the cream" of students according to their own criteria, with others being left behind. More than that, from the early 80's a new type of school emerged- the "supra-regional schools". Those schools requested, and sometimes received the permission to act as supra-regional

\footnotetext{
${ }^{38}$ A. Barak-Medina, op. cit., p. 5.

39 S. Swirski, op. cit., p. 100.

${ }^{40}$ A. Barak-Medina, op. cit., p. 5.

${ }^{41}$ Ibidem.

42 Ibidem, p. 6.

${ }^{43}$ T. Harel Ben Shahar, op. cit., p. 4.
} 
speciality schools, or registered from the beginning as unofficial education organizations. Those schools accepted students from everywhere into classes or whole schools specializing in media, sports or arts, as long as those students had passed the entrance exam and their families could afford the tuition. Those schools also known to exist in poorer communities, accepting students based on criteria such as religious backgrounds ${ }^{44}$. However, some of those unique schools are criticized for drawing all the strong students from surrounding schools, leading to reduction in achievement for the remaining student based on lack of strong peers to compare to ${ }^{45}$. Which means that those acceptable schools had put an additional dent in the supposed "integration".

Therefore, despite the initial legislation meant to create equal opportunities for students, some streams (such as the Orthodox) still use public resources, while being selective and maintaining segregation.

\section{Current situation}

\section{Numbers and changes}

At 2016-2017 school year Israel had 2665 elementary schools, out of which 1806 were official schools belonging to the accepted streams, budgeted $100 \%$ according to the state norm. In addition, there are 702 schools which are budgeted $75 \%$ from the state norm. Those schools are acknowledged, but aren't state-official. Those include independent schools, private ones, orthodox, non-state Arab schools. In total, elementary education system alone serves about 940,000 students. The schools are budgeted based on teaching hours, number of student, teacher quality and experience and hours dedicated to core lessons, such as mathematics and English ${ }^{46}$.

Several steps had been undertaken to promote equality. For example, the Compulsory Education Law (1949) has been extended to ages 5-16, and includes the right for free education (state covering $100 \%$ of basic tuition cost up to $12^{\text {th }}$ grade), in order to reduce dropping out. Additional legislation was also made to promote equality, such as the Student Rights Law (2000), proclaiming student equality regardless of gender, race, religion etc. In 2014 the law was further corrected including sexual orientation or gender identity.

Additional source of budgeting is the so called "grooming index" meant to promote students from lower social strata. For example, additional 20\% per capita budget are

\footnotetext{
${ }^{44}$ A. Barak-Medina, p. 9.

45 T. Harel Ben Shahar, p. 10.

${ }^{46}$ E. Weisblay, Tikzub batei sefer mukarim sheeinam rishmiim behinuch hayesodi venetutim hashvaatiim al mazavam hahevrati-kalkali shel batei sefer mimigzarim shonim (al pi meafjenej talmidim) [Budgeting of acknowledged unofficial elementary schools and comparative data on the socioeconomic state of schools from various sectors according to student data]. Jerusalem 2017.
} 
allocated for a school for each immigrant student from a poor country ${ }^{47}$. This model had been set to practice since 2009 in all levels of schools (elementary to high), and controls not only out right financial inflow, but also the size of classes (smaller for population in need) and additional teaching hours. This system is relevant to all acknowledged streams of education.

There are three main inherited currents in education. The state education is meant for non-religious schools in all sectors and nationalities in an equal measure. The state-religious schools exist only in the Jewish community. Those schools have religious inspectors and pay more attention to religious studies, but they still follow the core subject requirement. The third stream is the unique and orthodox schools, partially acknowledged and partially subsidized by the state ${ }^{48}$.

\section{Maintaining flaws}

Since the rise of the state, the education in Israel is mostly unchanged regarding segregation by nationality and levels of religiosity. For example, there's a secular Jewish system, orthodox and Arab. The state schools are financed mostly by the government, while the private and semi-private schools are financed partially, based on state acknowledgement of the school's program ${ }^{49}$.

The budgeting issue also shows itself in more than just supporting one stream or the other. The current Israeli population is used to the thought that the minimal parental payments only offer the most basic school services, while additional enrichment programs, which allow the pupil better chance in the future, are to be financed privately by the parents, and are known to reach 1500 NIS (about 450USD) for a single month ${ }^{50}$. The schools with the additional programs are usually marked low on eligibility for "grooming budget" 51 , but the parental investment is sufficient to provide better than average conditions.

While the system as a whole seeks to change, some of the flaws inherited from the pre-Israeli and the early stratified period had remained. One of the major shortcoming is the upkeep of the homogenous classes. Data from 2004 has shown that while repatriates

\footnotetext{
${ }^{47}$ Chief Scientist Office, Madad hatipuah [The grooming index] 2020. Accessed at https://edu.gov.il/sites/ ChiefScientist/measure/Pages/ses-index.aspx.

${ }^{48}$ E. Weisblay \& A. Wininger, Maarechet hahinumch be-Israel-sugiyot nivharot bethum isuka shel veadat ha hinuch, hatarbut vehasport shel ha-Knesset [The Education system in Insrael - selected issues in the works of the Education, Culture and Sports committee in the Knesset]. Jerusalem 2015. Retrieved from https://m. knesset.gov.il/Activity/Info/MMMSummaries19/Education.pdf.

49 S. Swirski \& N. Dagan-Buzgalo, Education reform: making education work for all children. Adva center, Tel-Aviv: 2011, p. 20.
50 S. Swirski et al., p. 51.
${ }^{51}$ Chief Scientist Office, op. cit. 
from ex-Soviet countries had been $2 \%$ of the population, in some schools they were about 6 times higher percent of the class contingent, and in some classes they were a clear majority ${ }^{52}$.

\section{New trends in education}

One of the new trends in Israeli education is an attempt to mix Arab Israeli and Jewish students in several schools defining themselves as bilingual, teaching in both Arabic and Hebrew. The first such institution was opened as a kindergarten in 1984, later growing into a school class. Currently there are 8 bilingual schools in Israel, catering to about 1700 students. Such schools receive full finding as state schools, without any extra financial incentive- thus making the idea privately-guided, but government-funded ${ }^{53}$.

Another known trend is the Democratic school. Those schools offer time allocation for teacher-student dialogue and mentorship programs where a teacher is responsible for 12-13 students, less than $50 \%$ of the average Israeli class. Currently those schools are extremely selective on the students accepted and mostly rely on private financing, but the process is already known ${ }^{54}$.

Therefore, some of the trends seek to promote integration among the Jews and Arabs, while others further maintain the private non-state segregating and selective image.

\section{Summary}

During over 100 years, the pre-Israeli and Israeli Education Systems had faced constant challenges of coping with diverse populations. The legislation had constantly adjusted to the challenges of the period, however loopholes were always found to maintain segregation and inequality ${ }^{55}$. Even in the $21^{\text {st }}$ century, the system faces various forms of segregation, some of which coming from the willing choice of the population, such as the Orthodox Jews, while others are a result of policies of cream-picking schools ${ }^{56}$.

Still, a change is visible, some led by the state in the form of corrective "grooming" budget and legislation forbidding segregation and equality, and other led by private schools. As opposed to the private schools of the past, those schools use the limited freedom of the law in order to form ethnically diverse classes and schools ${ }^{57}$.

${ }^{52}$ H. Ayalon et al., op. cit., p. 79.

53 A. Weininger, Bilingual institutions (Hebrew-Arabic) in the Education System. Jerusalem: Knesset. Retrieved from https://m.knesset.gov.il/EN/activity/mmm/Bilingual_Educational_Institutions.pdf [access: 21 of January 2019], p. 2

54 S. Swirski et al., op. cit., p. 43.

55 Ibidem, p. 212.

${ }^{56}$ A. Barak-Medina, p. 6.

${ }^{57}$ A. Weininger, p. 7. 
Future research is recommended to point out policy changes both on the diversity levels and on the deeper level of school functioning. Such research will allow to recognize the efficient use of school leadership in order to provide better education for the diverse society of Israel.

\section{Reference}

Al-Hamishmar, Memshelet MAPAI- Zionim Klaliim heevira ba-Knesset "Hok Hinuch Mamlachti" ubecach hisla zerem haovdim vehizka hazramim hadatiim [The MAPAI government had passed the State Education Law and by doing so has ended the Labour stream and strengthened the religious streams]. Al-Hamishmar 1968. Retrieved from http://jpress.org.il/olive/apa/nli_heb/ SharedView.Article.aspx?href=AHR/1968/04/30\&id=Ar04400.

Alboim-Dror R., Memshelet ha-mandat vehahinuch ha-ivri: tguvat hayeshuv lekolonializm tarbuti [The Mandate administration and the Hebrew education: the response of settlement to the cultural colonialism]. "Katedra" 1995, 75, 93-120.

Arar K., Israeli education policy since 1948 and the state of Arab education in Israel. "Italian Journal of Sociology of Education" 2012, 4(1), 113-145.

Ayalon H., Blass N., Feninger Y. \& Shavit Y., I shivyon behinuch memechkar lemediniyut [Educational inequality: from research to policy]. Jerusalem 2019.

Barak-Medina A., Hakzaat mash'abim behinuch, ikaron haintegracia vebatei sefer yehudiim bemigzarim shonim [Resource allocation in education, the integration principle and unique schools in different sectors]. Jerusalem 2003. Retrieved from: https://fs.knesset.gov.il/globaldocs/MMM/ 16e41ac7-9332-e811-80de-00155d0a0235/2_16e41ac7-9332-e811-80de-00155d0a0235 11_6987.pdf.

Chen M., Levy A. \& Adler H., Hativat habeinaim: halich vetozaa bemisrad hahinuch: lehaarachat truma shel hativat habeinaim lemaarechet ha hinuch [The middle school: process and outcome in the Ministry of Education: for assessing the input of middle school to the Education system]. Jerusalem 1978.

Chief Scientist Office Madad hatipuah [The grooming index]. Accessed at https://edu.gov.il/sites/ ChiefScientist/measure/Pages/ses-index.aspx, 2020.

Davidson M., The rise and the implementation of the State Education Law, 1953 [Doctoral dissertation]. Tel-Aviv 2002.

Gazi‘el H.., Politics and policy-making in Israel's education system. Sussex 1996.

Greenberg E., Preparing the mothers of tomorrow: education and Islam in mandate Palestine. Austin 2010.

Harel Ben-Shahar T., Asdara shel batei sefer pratiim bareranim: beit sefer Havrota kemikre mivhan [Regulation of private selective schools: Havrota school as case study]. Jerusalem 2012.

Kashti I., Maarechet haHinuch beIsarael: hinuch betkufat hamandat habriti [The education system of Israel: education in the British Mandate era], in: Ishim ve-maasim beIsrael: sefer hayovel, eds. S. Aharoni \& M. Aharoni.

Knesset, Hok Hinuch Mamlachti - 1953; Hok Limud Hova - horaot shaa - 1953 Kria rishona [The State Education law - 1953; Compulsory Education law - temporary orders - 1953. First reading]. Jerusalem 1953.

Rahman H., Education in Palestine: Current challenges and emancipatory alternatives, El-Bireh, 2015.

Resnik J. 'Sites of memory' of the Holocaust: shaping national memory in the education system in Israel. "Nations and nationalism" 2003, 9(2), 297-317. 
Shwed U., Shavit Y., Dellashi M. \& Ofek M., Policy paper 2014.12. Integration of Arab Israelis and Jews in schools in Israel, Israel 2014.

Swirski S., Hinuch be-Israel: mahoz hamaslulim hanifradim [Educaiton in Israel: schooling for inequality]. Tel Aviv 1990.

Swirski S. \& Dagan-Buzgalo N., Education reform: making education work for all children. Tel-Aviv 2011.

Tnuat Ha-Avoda, Hinuch betkufat hamandat [Education during the Mandate]. Retrieved from https://tnuathaavoda.info/education/home/7/1109679617.html [access: 2019].

Weininger A., Bilingual institutions (Hebrew-Arabic) in the Education System. Jerusalem: Knesset. Retrieved from https://m.knesset.gov.il/EN/activity/mmm/Bilingual_Educational_Institutions. pdf [access: 21 of January 2019].

Weisblay E., Tikzub batei sefer mukarim sheeinam rishmiim behinuch hayesodi venetutim hashvaatiim al mazavam hahevrati-kalkali shel batei sefer mimigzarim shonim (al pi meafjenej talmidim) [Budgeting of acknowledged unofficial elementary schools and comparative data on the socioeconomic state of schools from various sectors according to student data], Jerusalem 2017.

Weisblay E. \& Wininger A., Maarechet hahinumch be-Israel—sugiyot nivharot bethum isuka shel veadat ha hinuch, hatarbut vehasport shel ha-Knesset [The Education system in Insrael- selected issues in the works of the Education, Culture and Sports committee in the Knesset]. Jerusalem: 2015 Retrieved from https://m.knesset.gov.il/Activity/Info/MMMSummaries19/Education.pdf.

Zondberg A., Bein hurban lanizahon-mashmaut ha Shoah berei haitonim hayomiim beisrael 19482003 [Between destruction and victory - the meaning of Holocaust as represented in the daily Israeli newspapers 1948-2003], in: Sikur kesipur, mabatim al siah hatikshoret be-Israel, eds. M. Neiger, M. Blondheim \& T. Libs (pp. 191-215). Israel 2008.

https://www.netanya.ac.il/Lecturers/DocLib1/Between-Destruction-and-Victory.pdf.

Hok Hinuch Mamlachti [State Education Law], Sefer Ha-hukim 181, 137.

Hok Limud Hova [Compulsory Education Law], Sefer Ha-hukim 5709, 287.

Hok Zhujot Talmid [Student Rights Law], Sefer Ha-hukim 5765, 42, 401.

Pkudat Ha Hinuch [The Education bill], Hukei Eretz-Israel, A(C), 593. 